Article

\title{
Collective Civic Petitions in Urban Neighborhoods: A Comparative Study between Two Different-Tier Chinese Cities
}

\author{
Le Tang ${ }^{1}$, Fengqin Zhou ${ }^{2, *}$, Xueliang Feng ${ }^{1}$ and Yali Luo ${ }^{1}$ \\ 1 Faculty of Architecture and Civil Engineering, Huaiyin Insitition of Technology, Huai'an 223001, China; \\ tangle910365@sina.com (L.T.); fengxl@radi.ac.cn (X.F.); luoyl8502@sohu.com (Y.L.) \\ 2 Faculty of Foreign Language, Huaiyin Insitition of Technology, Huai'an 223001, China \\ * Correspondence: zhoufenqinha@126.com; Tel.: +86-517-8359-1157
}

Received: 1 November 2018; Accepted: 5 December 2018; Published: 7 December 2018

\begin{abstract}
This paper engages with civic development in urban neighborhoods in China after the period of reform that began in 1978. Examining the collective civic petitions that have occurred in urban neighborhoods, the paper offers a comparative analysis of changing trends, internal mechanisms, and their spatial distribution between two different-tier cities. Data pertaining to the collective civic petitions was drawn from open archives in two municipal bureaus, and related to the years 2013 to 2015. The data was then split into three types of petition typology-claim, protest, and hybrid. Certain similarities and differences emerged from the analysis relating to the types of petition that have occurred against different petition counterparties, namely, state authorities, real developers, and property management companies. Similarities among the two cities could be capable of indicating advancing urban civic developments with internal mechanisms among petition typology and contexts of individual petitions. Differences among the two cities could be related to various differences in their urban contexts, and may also reflect different levels of citizen civic consciousness and behavior.
\end{abstract}

Keywords: civic development; collective civic petitions; urban neighborhoods; petition types; spatial concentrations

\section{Introduction}

Since the market-oriented reform that commenced in 1978, China has undergone rapid industrialization and urbanization. Concurrently, China's urban society has experienced drastic changes [1]. Describing social changes in urban China has been undertaken by academics from both China and the Western world. Within such studies, civic engagement has been adapted as the terminology for observing urban social changes, including social cohesion, social capital, and civic participation, within a context of the state's openness to citizens' civic actions [2-4]. Academically, civic engagement is highly connected to urban civic development at the urban neighborhood scale, and is commonly defined as citizens' collective awareness and participation in achieving common goods [2-5]. In seeking to achieve common goods for local communities, civic engagement is distinguished from other social actions [2].

Some empirical studies have suggested the growth of citizens' civic engagements in urban China, with the state's openness to citizen participation [6-14]. In the last three decades, hierarchical state authorities have established specialized petition systems (Xinfang), various public hearing practices, and even village-level direct elections, as responses to citizens' empowerment and civic engagement [12-14]. These systems and practices have proved effective in addressing citizens' non-political civic engagements, such as collective disputes with other stakeholders, collective claims 
of public goods, and civic environmental issues [14-16]. However, those political civic engagements, which primarily desired democratic reform, were mostly forbidden and even classified as illegal actions, as they represented ideological threats to China's one-party political system and its urban social stability [15-17].

Significantly, the emergence of citizens' awareness, with regard to protecting citizenship and legalized rights, has been widely acknowledged as the driving force for increased civic engagements at the urban neighborhood scale $[9,11,12]$. In addition to the existence of a range of studies that have been developed at the urban neighborhood scale, others have been developed at the city scale, and these have sought to illustrate aspects of civic development in China's cities [5,13-16]. None of these studies has illustrated the detailed civic developments amongst different Chinese cities, or the similarities and differences that exist. Numerous western studies have stated the different civic developments that have occurred among urban neighborhoods and cities within different socioeconomic contexts; many have had an especial focus on the differentiated levels of citizens' civic awareness and behavior [16-23]. In order to explore China's urban civic development, it is rational to develop such studies to include both city and urban neighborhood scales. This is for two reasons. First, within the period of market-oriented reform, the hierarchical structure of China's urban administration (with strong sociologist ideology) has been transformed so that there now exists hierarchical differentiations amongst China's cities [24-26]. Officially and academically, those hierarchical differentiations among China's cities are commonly classified as first-tier cities (mostly megacities, in geographic terms), second-tier cities (mostly large cities or big cities in geographic terms), third-tier cities (mostly medium-sized cities in geographic terms), and other lower-tier cities (including small cities and big towns). It is worth noticing that the different-tiers reflect the hierarchical differentiations of urban socioeconomic developments among cities; this suggests further different levels of civic development among different-tier cities [24-28]. Second, the urban neighborhoods, as the typical units of analysis in studying urban civic developments, are highly affected by the differentiated urban civic developments that have occurred among different-tiers cities. This further impacts upon individual's differentiated civic awareness and their behavior [16-18,29-34].

Consequently, the general research aim of this paper is to explore the current urban civic developments within Chinese different-tier cities, through the perspective of collective civic petitions that have occurred in urban neighborhoods (as the targeted petitions in this paper). Within this research, three research questions are answered. The first research question is about how urban civic development was processed according to the changes of those targeted petitions among two cities. The second research question is about how neighborhood contexts and petition contexts were internally correlated to the existence of those targeted petitions. The third research question is about how those targeted petitions were spatially distributed within the cities.

\section{Methodology and Data}

\subsection{General Research Paradigm and Research Approaches}

One comparative case study paradigm is applied to studying the targeted petitions from the two different-tier Chinese cities. The first section is the numerical analysis of the targeted petitions and the other petitions that have occurred in the two cities from 2013 to 2015. The targeted petitions were initially compared to other petitions that have occurred. These were then compared within the applied typology so as to present the similarities and differences that have occurred in civic engagements in urban neighborhoods. The second section is the statistical analysis that arose from examining the internal mechanisms of those targeted petitions, mainly in the form of correlation and logistic regression analysis $[5,20,34]$. Within the statistical analysis, the petition types, as dependent variables, were tested against correlations to the independent variables, including the territorial contexts of individual urban neighborhoods and the social contexts of individual petitions. The third section 
involved the spatial mapping of those targeted petitions within urban spatial strata. This was done with reference to the different petition types and petition counterparties $[18,19,34,35]$.

\subsection{Selection of Case Cities}

Two different-tier Chinese cities were selected; Nanjing City and Huai'an City. The two cities possess significant territorial, social, and economic differences, as indicated in Table 1 . The location of the two cities is presented in Figure 1. These various contextual differences are capable of guaranteeing the research rationality of selecting the case cities. The classification of the two cities as, respectively, second-tier and third-tier cities, also guarantees the research rationality as urban civic development is highly connected to urban socioeconomic development [2,36-38].

Table 1. Contextual differentiation in two case cities.

\begin{tabular}{lcc}
\hline \multicolumn{1}{c}{ Categories of City Contexts } & Nanjing & Huai'an \\
\hline Territorial Area $\left(\mathrm{Km}^{2}\right)$ & 6622.45 & $10,072.03$ \\
Urban Administrative Area $\left(\mathrm{Km}^{2}\right)$ & 653 & 330 \\
\hline Municipal Population $(\mathrm{M})$ & 8.19 & 3.83 \\
Urban Population $(\mathrm{M})$ & 5.41 & 1.66 \\
\hline City Hierarchy (2016) & Second-tier & Third-tier \\
\hline City GDP in 2016 (Billion RMB) & $10,503.02$ & 3048 \\
\hline
\end{tabular}

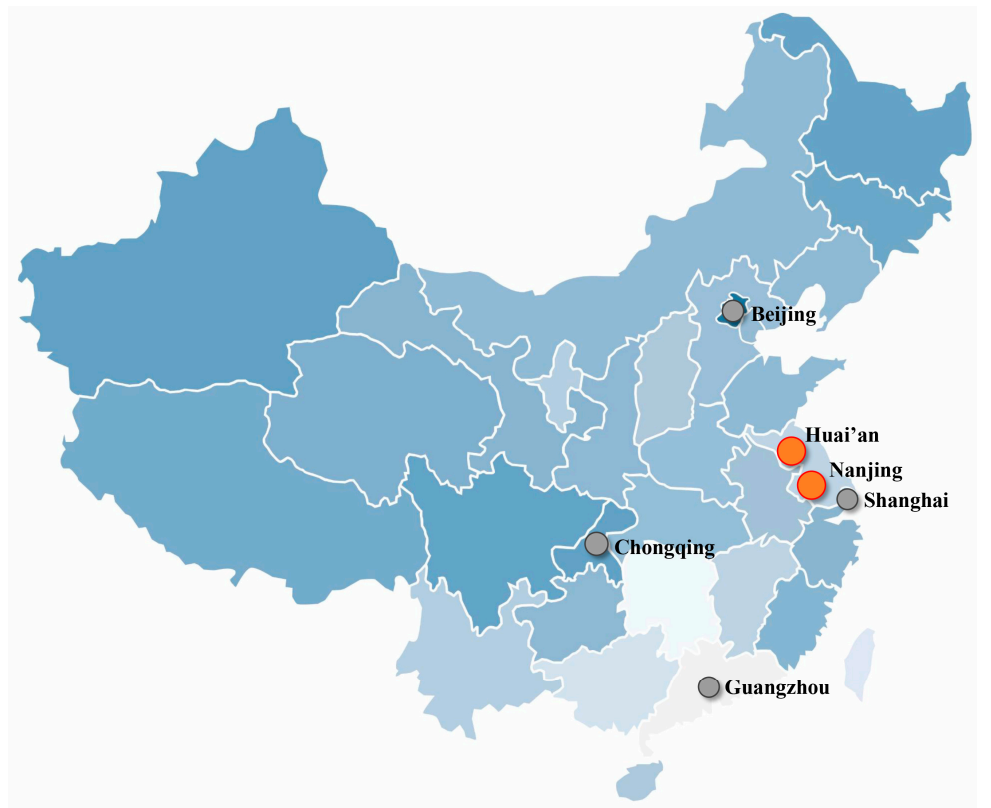

Figure 1. The location of the two different-tier cities: Nanjing City and Huai'an City.

\subsection{Data Collection and Coding}

Concerning the targeted petitions, the collective civic petitions that have occurred in the urban neighborhoods, along with other relevant data, was coded from the typology of the official petition documents. These official petition documents were collected from two Municipal Bureaus of People's Letter and Call (Renmin Xinfang Ju) in Nanjing City and Huai'an City. They consisted of open documents in the online archives and paper archives. In those open documents, all petitions were classified to have been effectively arbitrated. From 2013 to 2015, 188 petition documents were appealed to Nanjing Municipal Bureaus of People's Letter and Call, and 74 petition documents were appealed to the Huai'an Municipal Bureau of People's Letter and Call. Upon getting access to the petition documents, coding procedures were implemented to the petitions that had occurred in the urban 
neighborhoods; then, from among the petitions that had occurred in urban neighborhoods, those that were 'single' or 'non-civic' petitions were excluded.

(1) 'Single' means a petition with the signature of a single resident or household without any collaboration [2,39].

(2) 'Non-civic' means that the purpose of the petition was shaped to an individual's or certain group's interest [2,39].

After the identification of these targeted petitions, one event coding was implemented to generate documentary information. Six categories of distinct information were coded:

(1) Numerical information (e.g., the number of petitions that had occurred in the two case cities from 2013 to 2015, the number of petitions that had occurred in urban neighborhoods, and the number of collective civic petitions that had occurred in urban neighborhoods);

(2) Petition purpose (e.g., residents' claims, oppositions, and other requests in the petition document);

(3) Petition type (e.g., claim, protest, or hybrid);

(4) Petition counterparties (e.g., state authorities, property management companies, real developer, or others);

(5) Contextual information (e.g., event date, individual urban neighborhoods' locations, the size of individual urban neighborhood, as well as the time that has elapsed since the individual urban neighborhood were built);

(6) Households involvement in individual petitions (the number of families that signed the given petition).

Within this coded information, the typology of individual targeted petitions was subjectively developed according to the classification rules applied in the research about civic engagement in Chicago over three decades (1970-2000) [21]. Within the documentation on the purpose of the individual petitions, the individual targeted petitions were typed as claim, protest, or hybrid. The claim petitions explicitly stated the citizens' proactive demands pertaining to common goods or collective private goods from other stakeholders; the protest petitions explicitly illustrated the citizens' joint opposition and resistance to imprints from other stakeholders; the hybrid petitions were a blend of claim and protest petitions with citizens' explicit claims and resistant behaviors being noted. Due to the subjective attributes involved in coding procedures, the petition type was regarded as an independent variable in the statistical analysis, while the other categorizations of information were regarded as dependent variables.

\section{Changing Trends}

\subsection{General Trends}

The general conditions of petitions appealed to Municipal Bureaus of People's Letter and Call in the two cities from 2013 to 2015, and are presented in categories with hierarchically inclusive connections, including all petitions, petitions that have occurred in urban neighborhoods, and targeted petitions (Table 2). The first trend worthy of note is that the petitions which have occurred in urban neighborhoods experienced constant and significant growth in both cities. Although the total number of petitions also increased during the same period, these growths were relatively non-significant compared to the other two categories. For example, in Huai'an City, the annual average rate of change in the number of petitions appealed was $2.5 \%$, which is relatively insignificant compared to the annual growth of petitions that occurred in urban neighborhoods (13.2\%). Further, and regarding the constant growth of petitions that occurred in urban neighborhoods, the targeted petitions increased constantly to a rate of $15 \%$ in both cities. These numerical comparisons suggest that appealing petitions, whether individually or collectively, has been widely and increasingly applied by citizens in contemporary urban China. Moreover, the relatively higher growth of targeted petitions has occurred 
in parallel to rising property-led civic developments within commodity housing developments in urban China $[7,31,37]$.

Table 2. Petitions in Nanjing and Huai'an (2013-2015).

\begin{tabular}{|c|c|c|c|c|}
\hline & 2013 & 2014 & 2015 & Annual Average Changing Rate \\
\hline \multicolumn{5}{|c|}{ Nanjing } \\
\hline $\begin{array}{l}\text { All petitions (amounts) } \\
\text { (proportions) }\end{array}$ & $\begin{array}{c}113 \\
100 \%\end{array}$ & $\begin{array}{c}121 \\
100 \%\end{array}$ & $\begin{array}{c}135 \\
100 \%\end{array}$ & $6.1 \%$ \\
\hline $\begin{array}{l}\text { Petitions in urban neighborhoods (amounts) } \\
\text { (proportions) }\end{array}$ & $\begin{array}{c}71 \\
62.8 \%\end{array}$ & $\begin{array}{c}89 \\
73.6 \%\end{array}$ & $\begin{array}{c}99 \\
73.3 \%\end{array}$ & $11.7 \%$ \\
\hline $\begin{array}{l}\text { Targeted petitions (amounts) } \\
\text { (proportions) }\end{array}$ & $\begin{array}{c}49 \\
43.4 \%\end{array}$ & $\begin{array}{c}62 \\
51.2 \%\end{array}$ & $\begin{array}{c}77 \\
57.1 \%\end{array}$ & $16.3 \%$ \\
\hline \multicolumn{5}{|c|}{ Huai'an } \\
\hline $\begin{array}{l}\text { All petitions (amounts) } \\
\text { (proportions) }\end{array}$ & $\begin{array}{c}65 \\
100 \%\end{array}$ & $\begin{array}{c}66 \\
100 \%\end{array}$ & $\begin{array}{c}70 \\
100 \%\end{array}$ & $2.5 \%$ \\
\hline $\begin{array}{l}\text { Petitions in urban neighborhoods (amounts) } \\
\text { (proportions) }\end{array}$ & $\begin{array}{c}31 \\
47.7 \%\end{array}$ & $\begin{array}{c}39 \\
59.1 \%\end{array}$ & $\begin{array}{c}45 \\
64.3 \%\end{array}$ & $13.2 \%$ \\
\hline $\begin{array}{l}\text { Targeted petitions (amounts) } \\
\text { (proportions) }\end{array}$ & $\begin{array}{c}19 \\
29.2 \%\end{array}$ & $\begin{array}{c}24 \\
36.4 \%\end{array}$ & $\begin{array}{c}31 \\
44.3 \%\end{array}$ & $17.7 \%$ \\
\hline
\end{tabular}

Despite the general growing trends noted, as indicated in Table 2, another important trend is the increase in the number of targeted petitions in the two cities. From 2013 to 2015, targeted petitions increased from around 35\% (Nanjing, 43.4\%; Huai'an, 29.2\%) to around 50\% (Nanjing, 57.1\%; Huai'an, 44.3\%). However, at the urban neighborhood scale, there was a decrease in both single and non-civic petitions. These changes suggest that there has been increased citizen awareness with regard to raising civic engagement and achieving common good in urban neighborhoods. Those increasing trends also suggest that urban neighborhoods have been the main civic territories in urban civic developments $[8,40]$.

The increasing trends noted above all presented similar advancing civic developments in the two cities. However, it is significant to note that some differences still exist. Firstly, with regard to the number of petitions, the number in Nanjing City were significantly greater than those in Huai'an City. This difference could be related to the different urban populations and socioeconomic developments that exist between the two cities. Secondly, the relatively lower proportion of targeted petitions in Huai'an City may indicate the relatively lower level of civic development at the urban neighborhood scale in Huai'an City compared to Nanjing City.

\subsection{Trends of Targeted Petitions}

It was also noted that the similarities and differences between the two cities were quite significant with regard to the petition types, as indicated in Table 3. Similarly, the claim petitions experienced consistent growth in terms of both number and proportion. In contrast, the annual changes in terms of the number and proportion of protest and hybrid petitions were significantly different between the two cities. In Nanjing City, the claim petitions continually increased in amount and proportion; there was only a minor numerical change in the number of protest petitions, but there was a significant decrease in proportion. There was a continual increase in hybrid petitions, and the hybrid petitions had been the main type in 2015. In Huai'an City, protest petitions were the dominant type, and there has been growth in their number, as well as their proportion. The occurrences of hybrid petitions experienced minor growth in terms of number with a consistent decrease in proportion. These different trends in protest and hybrid petitions reflected individual's different awareness and behavior in their civic engagements [21]. Further, these different levels of consciousness and behavior could be connected to the different levels of civic development in Chinese different-tier cities; to a certain extent, citizens may be more affected by state authoritarian images in lower-tier developing cities $[2,8,16,18,41]$. 
Table 3. Collective civic petitions in urban neighborhoods by type (2013-2015).

\begin{tabular}{ccccc}
\hline & $\mathbf{2 0 1 3}$ & $\mathbf{2 0 1 4}$ & $\mathbf{2 0 1 5}$ & Annual Changing Rate \\
\hline \multicolumn{5}{c}{ Nanjing } \\
\hline Claim (amount) & 12 & 19 & 26 & $29.4 \%$ \\
(proportion) & $24.5 \%$ & $30.7 \%$ & $33.8 \%$ & $11.3 \%$ \\
\hline Protest (amount) & 21 & 23 & 19 & $-3.3 \%$ \\
(proportion) & $42.9 \%$ & $37.1 \%$ & $24.7 \%$ & $-16.8 \%$ \\
\hline Hybrid (amount) & 16 & 20 & 32 & $26.0 \%$ \\
(proportion) & $32.6 \%$ & $32.2 \%$ & $41.5 \%$ & $8.4 \%$ \\
\hline \multicolumn{5}{c}{ Huai'an } \\
\hline Claim (amount) & 5 & 8 & 10 \\
(proportion) & $26.4 \%$ & $33.3 \%$ & $32.3 \%$ & $26.0 \%$ \\
\hline Protest (amount) & 7 & 9 & 12 & $7.0 \%$ \\
(proportion) & $36.8 \%$ & $37.5 \%$ & $38.7 \%$ & $19.7 \%$ \\
\hline Hybrid (amount) & 7 & 7 & 9 & $1.6 \%$ \\
(proportion) & $36.8 \%$ & $29.2 \%$ & $29.0 \%$ & $8.7 \%$ \\
\hline
\end{tabular}

\subsection{Cross-Tabulation in Targeted Petitions}

Through cross-tabulating petition type and petition counterparties, the numerical changes of those targeted petitions were seen to be more variable in the two cities, as indicated in Table 4 . In Nanjing City, from 2013 to 2015, the state authorities were the dominant counterparties involved in all petitions, the real developers (RDs) were the least emerged counterparties, and the property management companies (PMCs) were the main counterparties in the hybrid petitions. In Huai'an City, the state authorities were rarely involved as counterparties in claim and hybrid petitions. By contrast, the PMCs were the main counterparties in all the targeted petitions-especially in claim and hybrid petitions. RDs became the dominant counterparties in claim petitions. That, in 2015, the RDs became the dominant counterparties in claim petitions occurred for several reasons, including the fact that several RDs tried to sell car parking spots to individuals against the original contracts.

Table 4. Collective civic petitions in urban neighborhoods by type and counterparties (2013-2015).

\begin{tabular}{|c|c|c|c|c|c|}
\hline \multirow{2}{*}{ Year } & & & \multicolumn{3}{|c|}{ Petition Counterparties } \\
\hline & & & State Authorities & Real Developers & PMCs \\
\hline \multicolumn{6}{|c|}{ Nanjing } \\
\hline \multirow{5}{*}{2013} & Claim & $\%$ & 83.3 & 8.3 & 8.3 \\
\hline & Protest & $\%$ & 76.2 & 14.3 & 9.5 \\
\hline & Hybrid & $\%$ & 37.5 & 25.0 & 37.5 \\
\hline & Total & $\%$ & 65.3 & 16.3 & 18.4 \\
\hline & Claim & $\%$ & 73.7 & 15.8 & 10.5 \\
\hline \multirow{3}{*}{2014} & Protest & $\%$ & 68.0 & 20.0 & 12.0 \\
\hline & Hybrid & $\%$ & 38.9 & 11.1 & 50.0 \\
\hline & Total & $\%$ & 68 & 16.1 & 22.6 \\
\hline \multirow{4}{*}{2015} & Claim & $\%$ & 68.0 & 25.0 & 12.0 \\
\hline & Protest & $\%$ & 68.4 & 21.1 & 10.5 \\
\hline & Hybrid & $\%$ & 40.6 & 9.4 & 50.0 \\
\hline & Total & $\%$ & 56.6 & 15.8 & 27.6 \\
\hline \multicolumn{6}{|c|}{ Huai'an } \\
\hline \multirow{5}{*}{2013} & Claim & $\%$ & 40.0 & 20.0 & 40.0 \\
\hline & Protest & $\%$ & 57.1 & 14.3 & 28.6 \\
\hline & Hybrid & $\%$ & 14.3 & 28.6 & 57.1 \\
\hline & Total & $\%$ & 36.8 & 21.1 & 42.1 \\
\hline & Claim & $\%$ & 37.5 & 25.0 & 37.5 \\
\hline \multirow{3}{*}{2014} & Protest & $\%$ & 44.4 & 22.2 & 33.3 \\
\hline & Hybrid & $\%$ & 14.3 & 42.9 & 42.9 \\
\hline & Total & $\%$ & 33.3 & 29.2 & 37.5 \\
\hline \multirow{4}{*}{2015} & Claim & $\%$ & 20.0 & 50.0 & 30.0 \\
\hline & Protest & $\%$ & 58.3 & 25.0 & 16.7 \\
\hline & Hybrid & $\%$ & 11.1 & 33.3 & 55.6 \\
\hline & Total & $\%$ & 32.3 & 35.5 & 32.3 \\
\hline
\end{tabular}


Similarly, in both cities, the state authorities always emerged as the main counterparties in the targeted petitions, and especially in protest petitions (with proportions over $65 \%$ ); by contrast, RDs rarely appeared as counterparties in the targeted petitions (with proportions less than $30 \%$ ), and PMCs were the main counterparties that emerged in the hybrid petitions. The differences between the two case cities were the different proportions of the various petitions against the PMCs.

\section{Internal Mechanisms}

\subsection{Correlation Analysis}

Citizens' civic awareness and behaviors in those targeted petitions could differ with regard to the different territorial and social contexts of individual urban neighborhoods, and also with regard to the different petition counterparties [20,34-36]. Consequently, the petition type was determined as the dependent variable in the statistical analysis. Table 5 indicates the comparative correlation analysis among dependent and independent variables in all the targeted petitions in the two cities for the years 2013 to 2015. Regarding the petition type, the correlation model confirmed the existence of internal mechanisms in those targeted petitions, and that there were a range of similarities that existed between the two cities. Among all the independent variables, the ages of individual urban neighborhoods and households involved were all significantly correlated to the petition type, while the housing size of individual urban neighborhoods was not vitally correlated to the dependent variable. By contrast, the petition counterparties were significantly correlated to the petition type in Nanjing City, but not significantly correlated in Huai'an City. These correlations enabled the further application of the logistic regression model to explore the relevant independent variables' correlations to the petition types.

Table 5. Correlation among dependent and independent variables.

\begin{tabular}{cccccc}
\hline & & $\begin{array}{c}\text { Ages of Urban } \\
\text { Neighborhoods }\end{array}$ & $\begin{array}{c}\text { Petition } \\
\text { Counterparty }\end{array}$ & $\begin{array}{c}\text { Housing } \\
\text { Size }\end{array}$ & $\begin{array}{c}\text { Households } \\
\text { Involved }\end{array}$ \\
\hline \multirow{2}{*}{ Petition type } & $\begin{array}{c}\text { Nanjing } \\
\text { Correlation } \\
\text { Sig. (2-tailed) }\end{array}$ & $0.240^{* *}$ & $0.346^{* *}$ & 0.020 & $0.299^{* *}$ \\
& 0.001 & 0.000 & 0.787 & 0.000 \\
\hline \multirow{2}{*}{ Petition type } & $\begin{array}{c}\text { Pearson } \\
\text { Correlation }\end{array}$ & $0.237^{*}$ & 0.164 & 0.155 & $0.353^{* *}$ \\
& Sig. (2-tailed) & 0.042 & 0.164 & 0.189 & 0.002 \\
\hline
\end{tabular}

${ }^{*}$ Correlation is significant at the 0.05 level (2-tailed). ${ }^{* *}$ Correlation is significant at the 0.01 level (2-tailed). ${ }^{1}$ Age of urban neighborhoods is the categorical variable explaining the built dates of individual neighborhoods, including pre-1998, 1999-2008, and after 2009 [39].

\subsection{Logistic Regression}

As indicated in Table 6, certain similarities and differences between the internal mechanisms of the targeted petitions emerged from the logistic model. The categorization involved in those independent variables was differently correlated to the petition type. Initially, and with reference to those correlations between the ages of urban neighborhoods and petition type, the statistical analysis suggests that targeted petitions might be more processed as the hybrid type in urban neighborhoods built between 1999 and 2008, which were similar in both cities. These similar correlations suggest the application of citizens' social capital in those hybrid petitions. This suggestion is in line with some existent empirical evidence about the neighboring environment in Chinese urban neighborhoods with regard to the highly heterogeneous nature of older neighborhoods and new neighborhoods [10-12,28-30,40]. There is no other significant correlation between the age of urban neighborhoods and the other two types of petitions-claim petitions and protest petitions. 
On another note, the involved households present significant correlations to the protest and hybrid petitions in the two cities. These similar correlations further indicate the application of citizens' social capital in determining civic awareness and behavior within the targeted petitions [21,41].

Table 6. Logistic regression on the correlated variables to petition types.

\begin{tabular}{|c|c|c|c|c|c|}
\hline \multicolumn{3}{|c|}{ Petition Type $^{1}$} & Beta & $\begin{array}{l}\text { Standard } \\
\text { Error }\end{array}$ & Sig. ${ }^{2}$ \\
\hline \multicolumn{6}{|c|}{ Nanjing } \\
\hline \multirow{4}{*}{ Protest } & \multirow{3}{*}{$\begin{array}{l}\text { Ages of urban } \\
\text { neighborhoods }\end{array}$} & Pre-1998 & 0.466 & 0.491 & 0.342 \\
\hline & & 1999-2008 & 0.033 & 0.521 & 0.949 \\
\hline & & After 2009 & -0.918 & 0.547 & 0.093 \\
\hline & \multicolumn{2}{|c|}{ Households Involved } & 0.021 & 0.009 & 0.015 \\
\hline \multirow{4}{*}{ Hybrid } & \multirow{3}{*}{$\begin{array}{l}\text { Ages of urban } \\
\text { neighborhoods }\end{array}$} & Pre-1998 & -1.960 & 0.638 & 0.002 \\
\hline & & 1999-2008 & 0.455 & 0.483 & 0.346 \\
\hline & & After 2009 & -1.266 & 0.563 & 0.025 \\
\hline & \multicolumn{2}{|c|}{ Households Involved } & 0.037 & 0.009 & 0.000 \\
\hline \multicolumn{6}{|c|}{ Huai'an } \\
\hline \multirow{4}{*}{ Protest } & \multirow{3}{*}{$\begin{array}{l}\text { Ages of urban } \\
\text { neighborhoods }\end{array}$} & Pre-1998 & 0.031 & 0.687 & 0.964 \\
\hline & & 1999-2008 & 1.301 & 0.843 & 0.123 \\
\hline & & After 2009 & -0.886 & 0.867 & 0.307 \\
\hline & \multicolumn{2}{|c|}{ Households Involved } & 0.020 & 0.016 & 0.043 \\
\hline \multirow{4}{*}{ Hybrid } & \multirow{3}{*}{$\begin{array}{l}\text { Ages of urban } \\
\text { neighborhoods }\end{array}$} & Pre-1998 & -2.214 & 1.191 & 0.049 \\
\hline & & 1999-2008 & 1.567 & 0.847 & 0.065 \\
\hline & & After 2009 & -1.876 & 0.987 & 0.050 \\
\hline & \multicolumn{2}{|c|}{ Households Involved } & 0.040 & 0.018 & 0.027 \\
\hline
\end{tabular}

${ }^{1}$ The reference category is the claim petition, with relative lower occurrences in two cities. ${ }^{2}$ Regression is significant at the 0.05 .

\section{Spatial Mapping}

The spatial mapping of those targeted petitions illustrated several similarities and differences with regard to the distribution of those targeted petitions in the two cities. Concerning the two cities, the spatial strata was set according to the historical urban territorial changes described in the city master plans of the last two decades, as indicated in Figures 2 and 3 [42-46]. 


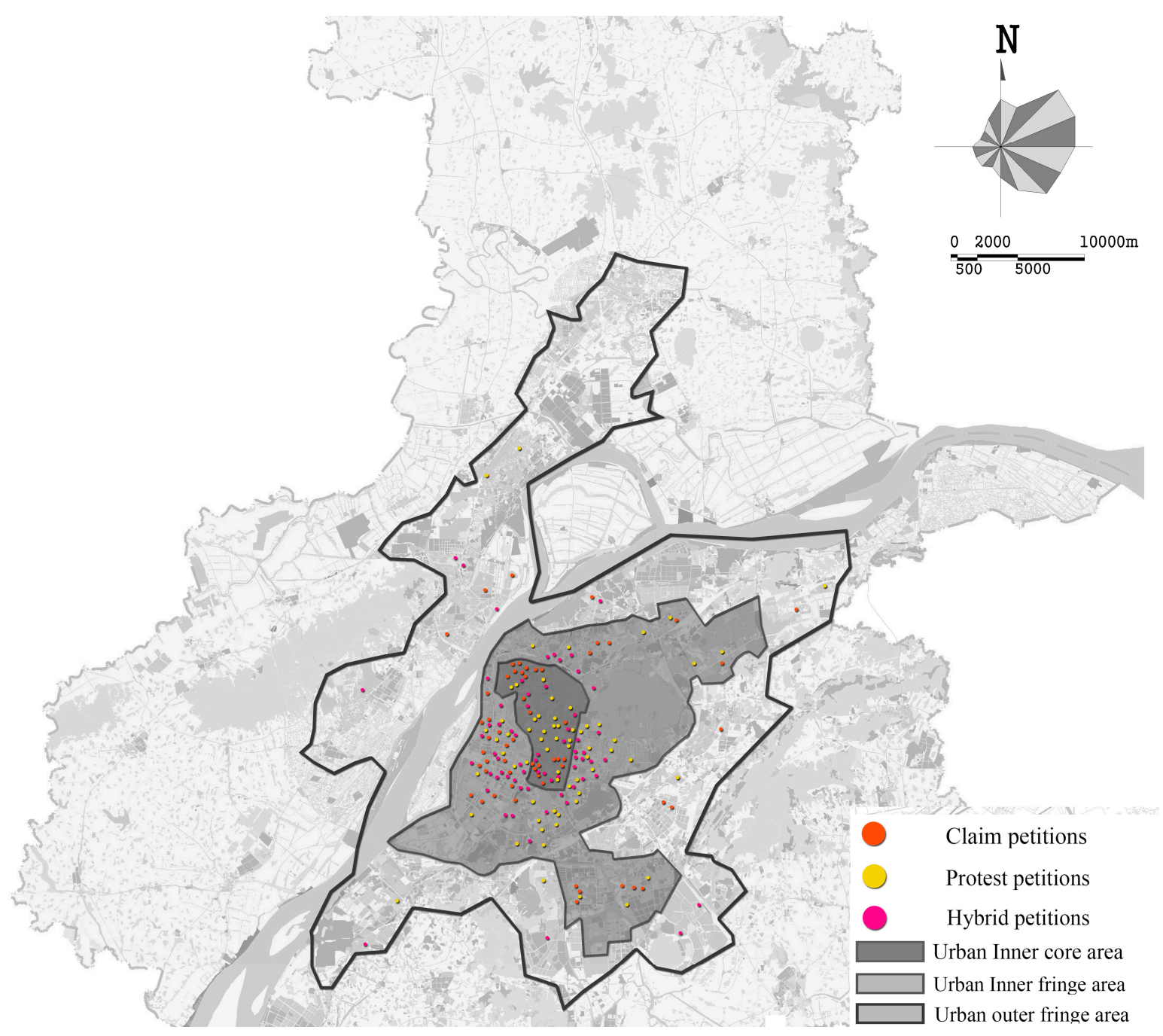

Figure 2. Location of collective civic petition in urban neighborhoods in Nanjing. 


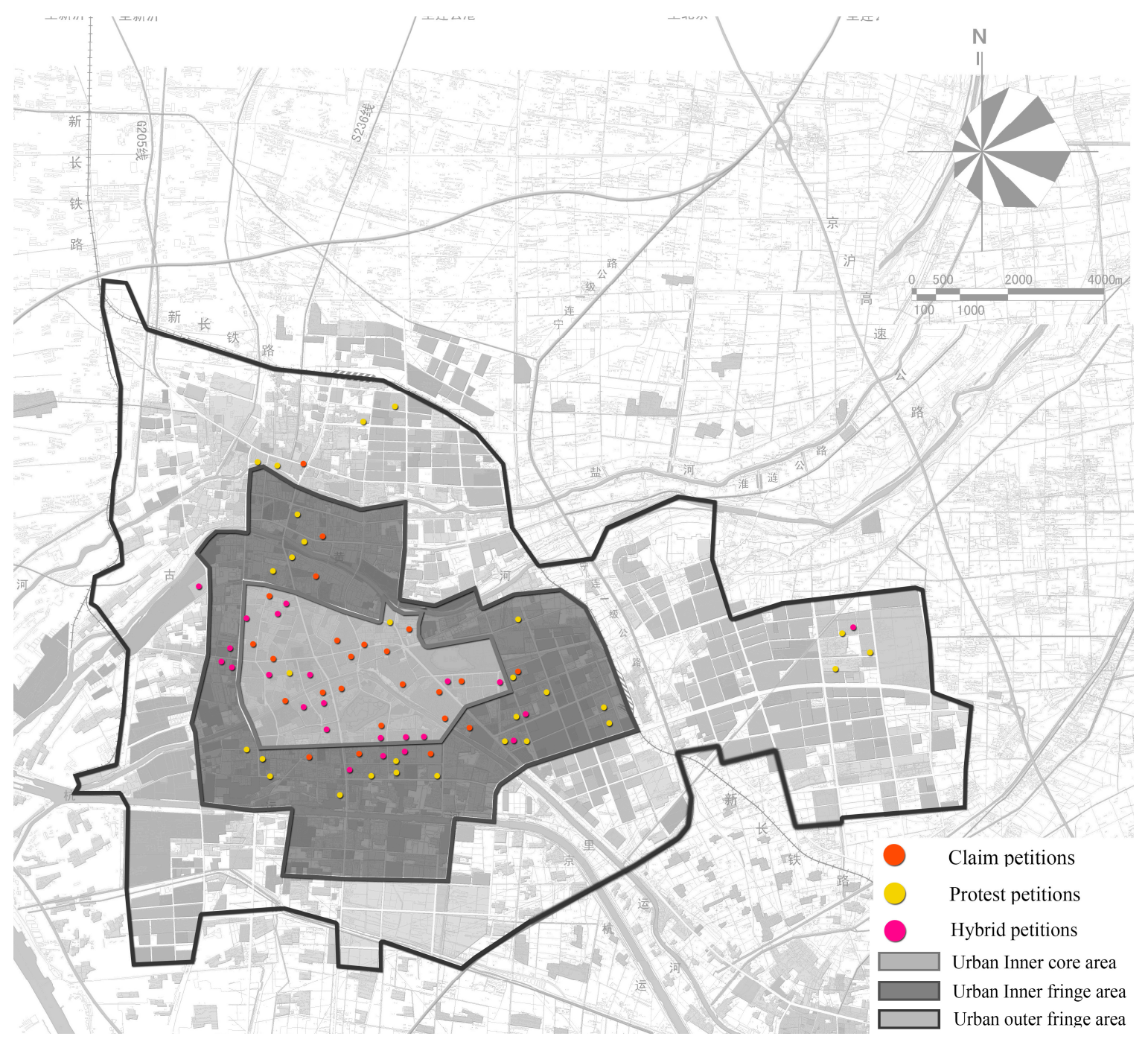

Figure 3. Location of collective civic petition in urban neighborhoods in Huai'an.

\subsection{Spatial Distribution}

As indicated in Figure 4, the mapping results suggested some similarities in the spatial distribution of the targeted petitions in both cities. All targeted petitions seem to have occurred in those urban neighborhoods that are located in the urban inner core areas and the inner fringe areas, whereas examples of targeted petitions were relative rare in those urban neighborhoods located in the urban outer fringe areas. The significant spatial concentrations in the inner core areas and inner fringe areas can be related to general housing developments within Chinese urban planning practices since the 1980s [39,42]. As indicated in the city master plans of the two cities, urban neighborhoods were progressively developed initially in urban inner core areas, and then in urban inner fringe areas [47-53]. Cumulatively, in the two cities, those radical urban renewals resulted in the relative concentration of urban neighborhoods in urban inner core areas and inner fringe areas [42]. As indicated in latest city master plans of the two cities, the residential areas are the main urban spaces in the urban inner spaces (including inner core areas and inner fringe areas), and account for $42.1 \%$ and $38.7 \%$ of population in Nanjing and Huai'an respectively $[50,53]$. However, despite these similar spatial concentrations, there also existed certain differences. In Nanjing City, all the targeted petitions were more located in the inner fringe areas than the inner core areas. Conversely, in Huai'an City, those targeted petitions, typed as claim and hybrid, were more often located in the inner core area; protest petitions tended to be located in the inner fringe area. 

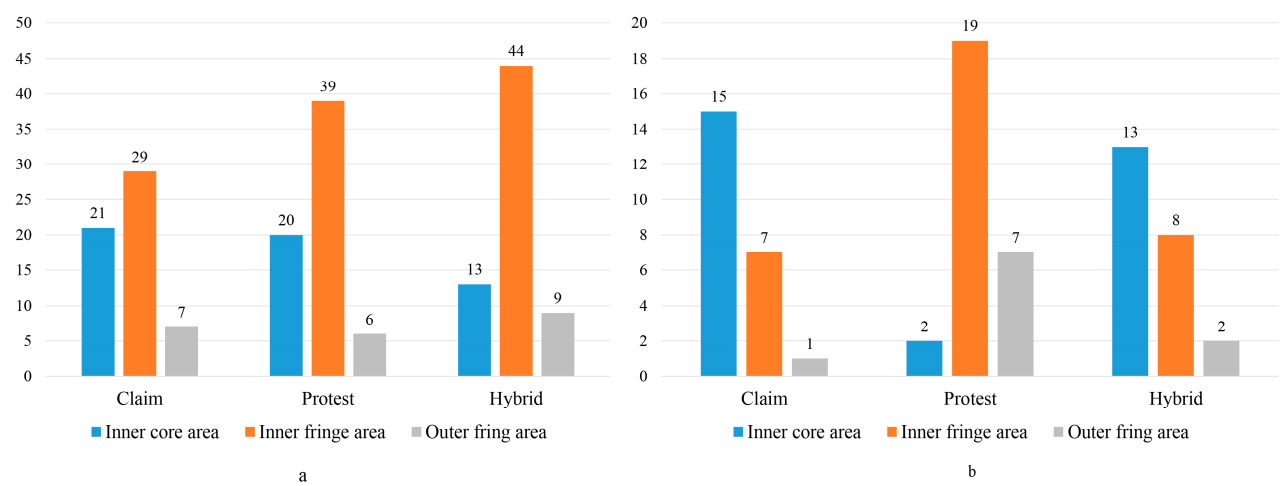

Figure 4. (a) Distributions of individual targeted petitions in urban stratums (Nanjing); (b) Distributions of individual targeted petitions in urban stratums (Huai'an).

Having cross-tabulated the petition types and petition counterparties, the mapping results suggest the existence of further similarities and differences with further spatial concentrations in the urban inner core and fringe areas, as indicated in Figure 5. With reference to claim and protest petitions, it can be noted that, in Nanjing City, most targeted petitions were raised against state authorities, with fewer being raised against RDs and PMCs. However, with regard to hybrid petitions, PMCs were the most numerous counterparties. In Huai'an City-and as a consequence of the more limited samples in the cross-tabulation - the only suggestion that emerges is that protest petitions located in the urban inner fringe area were mostly against state authorities. Consequently, regarding spatial concentration, it can be concluded that the protest petitions against state authorities tended to occur more often in the urban inner fringe areas of both cities.
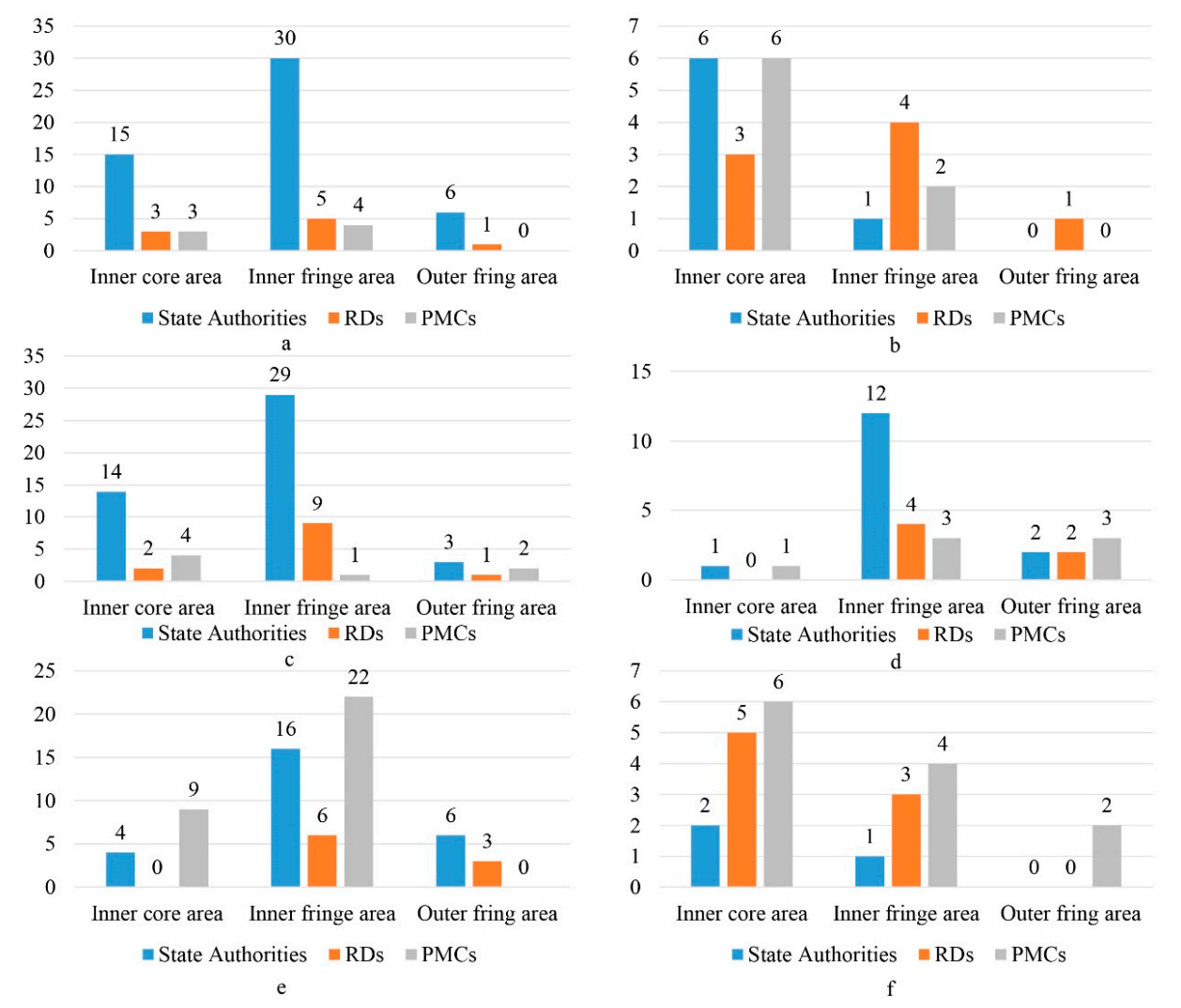

Figure 5. (a) Distributions of claim petitions in urban stratums, Nanjing; (b) Distributions of claim petitions in urban stratums, Huai'an; (c) Distributions of protest petitions in urban stratums, Nanjing; (d) Distributions of protest petitions in urban stratums, Huai'an; (e) Distributions of hybrid petitions in urban stratums, Nanjing; (f) Distributions of hybrid petitions in urban stratums, Huai'an. 


\subsection{Spatial Agglomeration}

Within those spatial concentrations, the mapping results further suggested the existence of spatial agglomerations among those targeted petitions, as indicated in Figures 6 and 7. Similarly, there emerged a number of spatial agglomerations comprised of protest petitions against the state authorities and hybrid petitions against PMCs. Regarding those protest petitions against state authorities, there were three spatial agglomerations (including more than three petitions) in urban inner fringe areas in Nanjing City; and two spatial agglomerations (including three petitions) in Huai'an city. Regarding the hybrid petitions against PMCs, there were three spatial agglomerations in Nanjing City, as one agglomeration (including four petitions) located in the inner core area and two (both including more than three petitions) located in the inner fringe area. Two spatial agglomerations emerged in Huai'an city, one (including three petitions) located in the inner core area, and another (including three petitions) located in the inner fringe area. Contrastingly, there were two spatial agglomerations of claim petitions against state authorities in Nanjing City, but no such spatial agglomerations in Huai'an City.

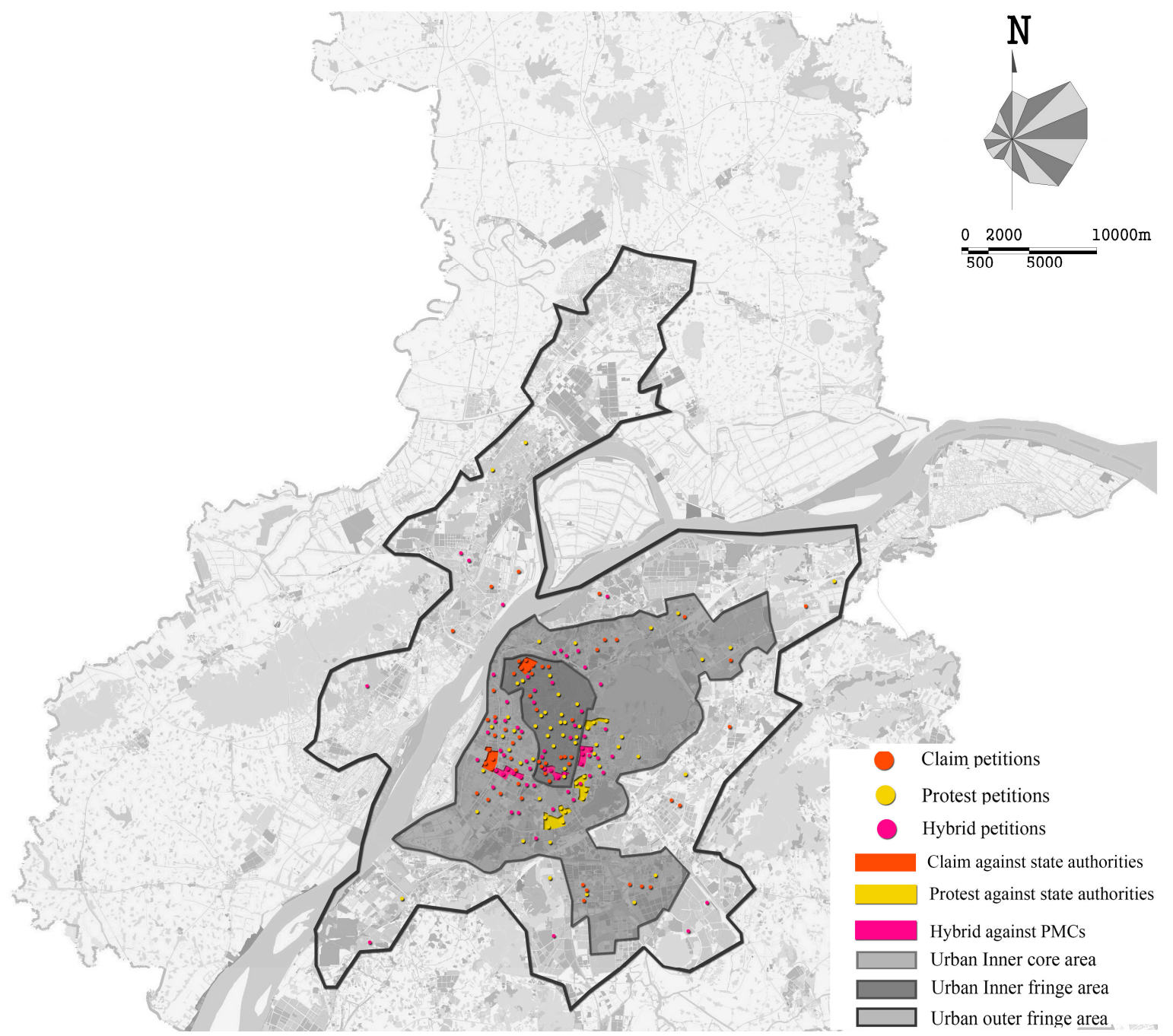

Figure 6. The spatial agglomeration of collective civic petitions in urban neighborhoods in Nanjing. 


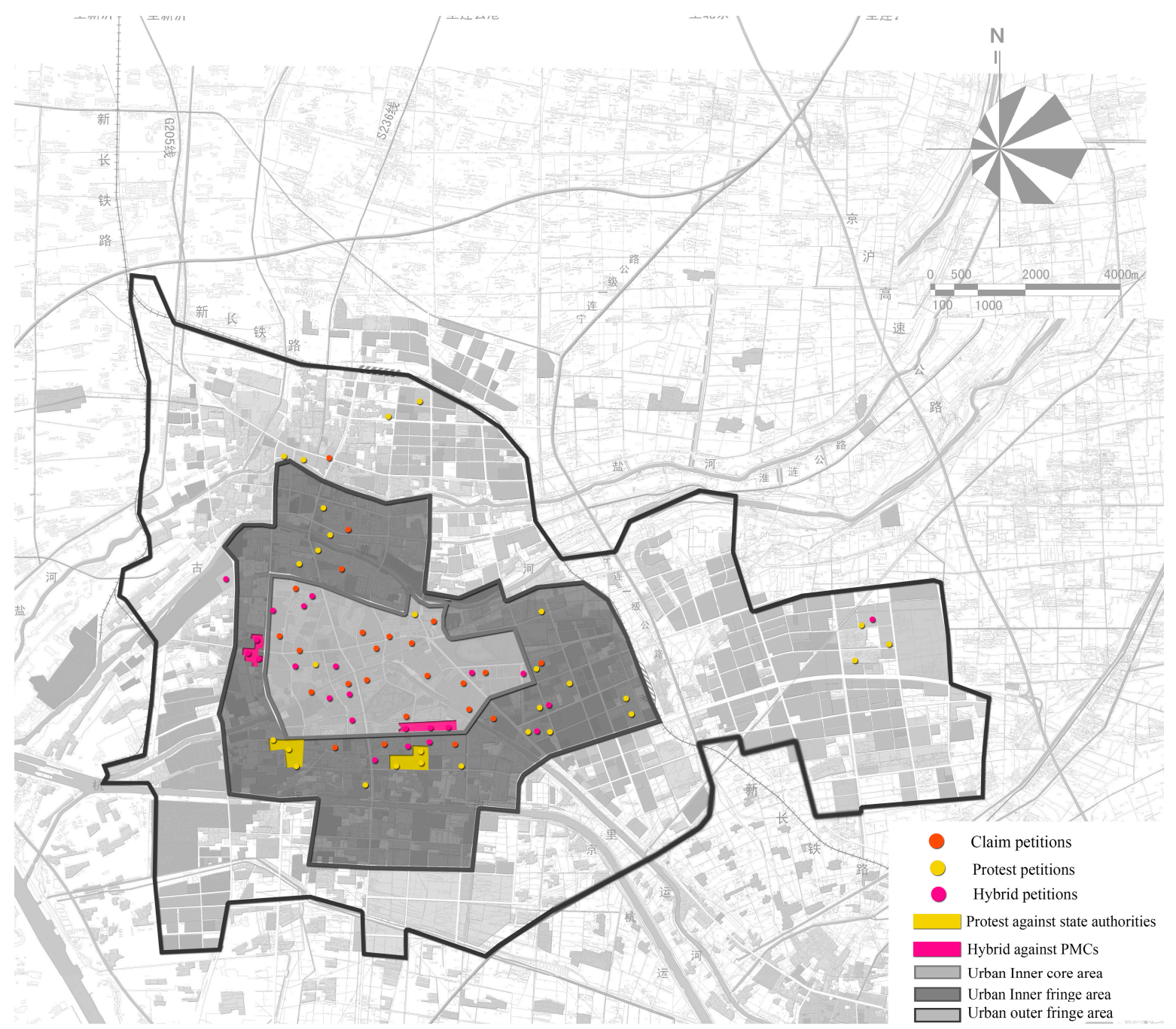

Figure 7. The spatial agglomeration of collective civic petitions in urban neighborhoods in Huai'an.

\section{Research Findings}

Based on the typology of all the targeted petitions in the two cities, the series paralleling analysis presented several similarities and differences pertaining to civic engagements in the two cities' respective urban neighborhoods. These similarities were qualified by reflecting upon citizens' raised civic awareness and behavior with regard to advancing contemporary civic developments in urban China. The differences that were found through the analysis may well illustrate the existence of different levels of urban civic development between different-tier cities that possess socioeconomic differences.

\subsection{Advancing Urban Civic Engagements}

As indicated through the numerical analysis, targeted petitions were the most numerous type of petition in the two cities. At the city scale, the increased number and proportion of targeted petitions suggests that urban neighborhoods have been the main civic territories for raising civic engagements in both cities [36,53]. This is similar to the findings of some western empirical studies about civic development and socioeconomic changes with regard to urban neighborhoods' size, and the effects of increasing residential density caused through rapid urbanization [53]. At the individual urban neighborhood scale, the growing trend of appealing collective civic petitions witnessed a consistent decrease in 'single' and 'non-civic' petitions. However, the differences in the proportions of targeted petitions suggest that there has been greater advancement of citizens' civic engagements in the 
second-tier city, Nanjing City, than the third-tier city, Huai'an City. Corresponding to this different level of civic development, the differences that emerged with regard to the comparisons between petition types also reflected a more advanced civic development in Nanjing city. These research findings indicate a general growing trend of citizens appealing collective civic petitions in urban China, and certain different levels of urban civic development between these two different-tier cities.

\subsection{Internal Mechanisms within the Typology}

The statistical analysis presented the existence of internal mechanisms about the correlations among petition types and the various contexts in individual targeted petitions. To the petition type as the dependent variable, the correlation models stated the similar correlations from two independent variables, including ages of individual urban neighborhoods and households involved in individual petitions. As the territorial context, the ages of individual urban neighborhoods reflected the social networks among neighbors within long-term acquaintances; and, as the petition context, the households involved reflected the citizens' trust and reciprocities in making collective decisions [3,4]. Consequently, these internal mechanisms, among two independent variables and petition types, presented the strong application of social capital in citizens' collective civic resistances [2-5]. Further, the logistic regression model suggested that the hybrid petitions had occurred less in the urban neighborhoods with ages over 20 years (pre-1998) or less than 10 years (after 2009). This correlation might indicate the different conditions of neighbors' social capital within Chinese urban housing developments, with high heterogeneity in the renewed old neighborhoods (pre-1998) and new neighborhoods (after 2009). Besides that, there existed significant correlation among petition types and counterparties in the targeted petitions in Nanjing city, but no such correlation existed in Huai'an. This correlation further suggested the more advanced civic development in the second-tier city, as citizens had more oriented civic awareness and behaviors against certain counterparties.

\subsection{Spatial Concentration and Agglomerations}

As indicated in the spatial mapping, all targeted petitions tended to be located in the urban inner core areas and inner fringe areas of the two cities with similar urban spatial structure. In one aspect, these spatial concentrations can be related to Chinas' urban housing developments within the similar urban renewal procedures in the radical forms from inner core area to inner fringe area. Moreover, by cross-tabulating petition types and petition counterparties, the mapping results suggest that certain spatial agglomerations exist in the urban inner core areas and the inner fringe areas of the two cities. These spatial agglomerations further suggest the existence of potential spillover effects among individual targeted petitions. However, with regard to the spatial agglomerations, there were differences in their number and composition between the two cities; there were significantly more in Nanjing City. In addition, there was only evidence of spatial agglomerations of claim petitions against state authorities in Nanjing City.

\section{Conclusions}

With typological analysis applied to those targeted petitions in years 2013 to 2015, this paper suggests several important research findings with regard to improving urban civic developments in two different-tier Chinese cities. The collective civic petitions had been increasingly and widely applied by citizens in resistance against imprints from other stakeholders, including state authorities, RDs, and PMCs. Urban neighborhoods had been the main civic territory in advancing urban civic developments. Some petition contexts presented significant correlations to the different petition types, and those correlations indicated the application of social capital in citizens' civic engagements [4-6]. Similar spatial agglomerations, with regard to targeted petitions, include protest petitions against state authorities and hybrid petitions against PMCs, which emerged in urban inner core areas and inner fringe areas. However, these identified differences reflected different levels of advancing civic development between two Chinese different-tier cities. These differences were also consistent with 
some empirical research findings about differences between civic engagements pertaining to different socioeconomic contexts [6,20,35].

The research findings from this paper also raise some new research subjects and directions pertaining to contemporary China's urban civic development. In one aspect, in subjects of urban studies, studying the efficacy of civic engagement could be enable observation of the social changes with highly socioeconomic homogeneity in individual urban neighborhoods [19,30,34,54]. Another aspect, in the subjects of urban political and social studies, is the increasing trends of applying collective civic petitions against state authorities which indicate more opportunities on observing the changes in citizens' participation in urban China, as climbing the ladder of citizen participation, within the socialist states' bounded administrations on civic engagements $[1,17,18,55]$.

Author Contributions: L.T. designed the analytical framework, and wrote and revised the paper. F.Z. co-wrote and revised the paper. X.F. constructed the model and analyzed the data. Y.L. assisted the collection of research data. All authors read and approved the final manuscript.

Funding: This research received no external funding.

Acknowledgments: This study was partially supported by Science and Technology Project of China's Ministry of Housing and Urban-Rural Development (2018-R2-031).

Conflicts of Interest: The authors declare no conflicts of interest.

\section{References}

1. Bian, Y.; Logan, J.R. Market transition and the persistence of power: The changing stratification system in urban China. Am. Sociol. Rev. 1996, 61, 739-758. [CrossRef]

2. Adler, P.; Goggin, J. What do we mean by "civic engagement"? J. Transform. Educ. 2005, 3, 236-253. [CrossRef]

3. Son, J.; Lin, N. Social capital and civic action: A network-based approach. Soc. Sci. Res. 2008, 37, 330-349. [CrossRef]

4. Putnam, D. Bowling alone: America's declining social capital. In Culture and Politics; Palgrave Macmillan: New York, NY, USA, 2000; pp. 223-234.

5. Hu, K.; Chan, R. Social capital and civic engagement in urban China. Int. J. Soc. Qual. 2012, 2, $24-42$. [CrossRef]

6. Read, L. Democratizing the neighbourhood? New private housing and home-owner self-organization in urban China. China J. 2003, 49, 31-59. [CrossRef]

7. Wu, F. The poverty of transition: From industrial district to poor neighbourhood in the city of Nanjing, China. Urban Stud. 2007, 44, 2673-2694.

8. Fu, Q.; Lin, N. The Weaknesses of Civic Territorial Organizations: Civic Engagement and Homeowners Associations in Urban China. Int. J. Urban Reg. Res. 2014, 38, 2309-2327. [CrossRef]

9. He, S. Homeowner associations and neighborhood governance in Guangzhou, China. Euras. Geogr. Econ. 2015, 56, 260-284. [CrossRef]

10. Liu, Y.; Wu, F.; Liu, Y.; Li, Z. Changing neighbourhood cohesion under the impact of urban redevelopment: A case study of Guangzhou, China. Urban Geogr. 2017, 38, 266-290. [CrossRef]

11. Zhang, L. Forced from home: Property rights, civic activism, and the politics of relocation in China. Urban Anthropol. Stud. Cult. Syst. World Econ. Dev. 2004, 33, 247-281.

12. Wang, W.; Hui, L.; Terry, L. Civic engagement and citizenship development: The case of homeowners' participation in neighborhood affairs in Beijing. Adm. Soc. 2017, 49, 827-851. [CrossRef]

13. Cheng, Y.; Liang, J.; Leung, L. Social network service use on mobile devices: An examination of gratifications, civic attitudes and civic engagement in China. New Media Soc. 2015, 17, 1096-1116. [CrossRef]

14. Shao, G.; Lu, J.; Wu, J. New media and civic engagement in China: The case of the Xiamen PX event. China Media Res. 2012, 8, 76-82.

15. Tang, S.; Zhan, X. Civic environmental NGOs, civil society, and democratisation in China. J. Dev. Stud. 2008, 44, 425-448. [CrossRef]

16. Leggett, A. Online Civic Engagement and the Anti-domestic Violence Movement in China: Shifting Norms and Influencing Law. VOLUNTAS Int. J. Volunt. Nonprofit Organ. 2017, 28, 2251-2277. [CrossRef]

17. Arnstein, S.R. A ladder of citizen participation. J. Am. Inst. Plan. 1969, 35, 216-224. [CrossRef] 
18. Andrews, R. Civic culture and public service failure: An empirical exploration. Urban Stud. 2007, 44, 845-863. [CrossRef]

19. Andrews, R. Civic engagement, ethnic heterogeneity, and social capital in urban areas: Evidence from England. Urban Affairs Rev. 2009, 44, 428-440. [CrossRef]

20. Pattie, C.; Patrick, S.; Paul, W. Citizenship and civic engagement: Attitudes and behaviour in Britain. Political Stud. 2003, 51, 443-468. [CrossRef]

21. Sampson, R.J.; McAdam, D.; MacIndoe, H.; Weffer-Elizondo, S. Civil society reconsidered: The durable nature and community structure of collective civic action. Am. J. Sociol. 2005, 111, 673-714. [CrossRef]

22. Saegert, S. Building civic capacity in urban neighborhoods: An empirically grounded anatomy. J. Urban Affairs 2006, 28, 275-294. [CrossRef]

23. Cohen, M.; Wiek, A.; Kay, B.; Harlow, J. Aligning public participation to stakeholders' sustainability literacy-A case study on sustainable urban development in Phoenix, Arizona. Sustainability 2015, 7, 8709-8728. [CrossRef]

24. Reese, A.; Rosenfeld, R.A. The Civic Culture of Local Economic Development; Sage: Thousand Oaks, CA, USA, 2002.

25. De Souza Briggs, X. Democracy as Problem Solving: Civic Capacity in Communities across the Globe; MIT Press: Cambridge, CA, USA, 2008.

26. Chen, A.; Partridge, M.D. When are cities engines of growth in China? Spread and backwash effects across the urban hierarchy. Reg. Stud. 2013, 47, 1313-1331. [CrossRef]

27. Li, H.; Wei, Y.D.; Liao, F.H.; Huang, Z. Administrative hierarchy and urban land expansion in transitional China. Appl. Geogr. 2015, 56, 177-186. [CrossRef]

28. Chen, Y.; Wu, Y. Regional economic growth and spillover effects: An analysis of China's Pan Pearl River Delta Area. China World Econ. 2012, 20, 80-97. [CrossRef]

29. Zhou, Y.; Ma, L.J. Economic restructuring and suburbanization in China. Urban Geogr. 2000, 21, $205-236$. [CrossRef]

30. Li, S.M.; Huang, Y. Urban housing in China: Market transition, housing mobility and neighbourhood change. Hous. Stud. 2006, 21, 613-623. [CrossRef]

31. Wang, X. Governmentalities in everyday practices: The dynamic of urban neighbourhood governance in China. Urban Stud. 2016, 53, 2330-2346.

32. Cai, Y. Local governments and the suppression of popular resistance in China. China Q. 2008, 193, $24-42$. [CrossRef]

33. Paik, W. Economic development and mass political participation in contemporary China: Determinants of provincial petition (Xinfang) activism 1994-2002. Int. Political Sci. Rev. 2012, 33, 99-120. [CrossRef]

34. Kim, Y.C.; Ball-Rokeach, S.J. Community storytelling network, neighborhood context, and civic engagement: A multilevel approach. Hum. Commun. Res. 2010, 32, 411-439. [CrossRef]

35. Manturuk, K.; Lindblad, M.; Quercia, R. Homeownership and civic engagement in low-income urban neighborhoods a longitudinal analysis. Urban Affairs Rev. 2012, 48, 731-760. [CrossRef]

36. Torney-Purta, J. Patterns in the civic knowledge, engagement, and attitudes of European adolescents: The IEA Civic Education Study. Eur. J. Educ. 2002, 37, 129-141. [CrossRef]

37. Yeh, A.G.O.; Wu, F. Internal structure of Chinese cities in the midst of economic reform. Urban Geogr. 1995, 16, 521-554.

38. Chinese Academy of Social Science. Report of Chinese Urban Competitiveness 2016; Chinese Academic of Social Science: Beijing, China, 2017.

39. Diller, E.C. Citizens in Service: The Challenge of Delivering Civic Engagement Training to National Service Programs; Corporation for National and Community Service: Washington, DC, USA, 2001.

40. Bray, D. Building 'community': New strategies of governance in urban China. Econ. Soc. 2006, 35, 530-549. [CrossRef]

41. He, S. Right to the city: A liberal-democratic perspective. In International Encyclopedia of the Social E Behavioral Sciences; Elsevier: Oxford, UK, 2015; pp. 673-679.

42. Wu, F. Commodification and housing market cycles in Chinese cities. Int. J. Hous. Policy 2015, 15, 6-26. [CrossRef]

43. Cheshire, P. Inner areas as spatial labour markets: A critique of the inner area studies. Urban Stud. 1979, 16, 29-43. [CrossRef] 
44. Gu, C.L.; Xiong, J.B. On urban fringe studies. Geogr. Res. 1989, 8, 95-101.

45. Nine, Y.M.; Yan, Z.M. The changing industrial and spatial structure in Shanghai. Urban Geogr. 1995, 16, 577-594.

46. Anas, A.; Richard, A.; Kenneth, A.S. Urban spatial structure. J. Econ. Lit. 1998, 36, 1426-1464.

47. Nanjing Urban Planning Bureau. Nanjing City Master Planning 2007; Jiangsu Institute of City Planning Co. Ltd.: Nanjing, China, 2007.

48. Nanjing Urban \& Rural Planning Bureau. Nanjing City Master Planning 2011; Jiangsu Institute of City Co. Ltd.: Nanjing, China, 2011.

49. Nanjing Urban \& Rural Planning Bureau. Nanjing City Master Planning 2016; Chinese Institute of Urban \& Rural Planning Co. Ltd.: Nanjing, China, 2016.

50. Huai'an Urban Planning Bureau. Huai'an City Master Planning 2005; Jiangsu Institute of City Planning Co. Ltd.: Huai'an, China, 2005.

51. Huai'an Urban \& Rural Planning Bureau. Huai'an City Master Planning 2009; Chinese Institute of Urban \& Rural Planning Co. Ltd.: Huai'an, China, 2009.

52. Huai'an Urban \& Rural Planning Bureau. Huai'an City Master Planning 2016; Jiangsu Institute of City \& Rural Planning Co. Ltd.: Huai'an, China, 2016.

53. Tavares, A.F.; Carr, J.B. So close, yet so far away? The effects of city size, density and growth on local civic participation. J. Urban Affairs 2013, 35, 283-302. [CrossRef]

54. He, S.; Wu, F. Socio-spatial impacts of property-led redevelopment on China's urban neighbourhoods. Cities 2007, 24, 194-208. [CrossRef]

55. Qian, C.; Zhou, Y.; Ji, Z.; Feng, Q. The Influence of the Built Environment of Neighborhoods on Residents' Low-Carbon Travel Mode. Sustainability 2018, 10, 823. [CrossRef]

(C) 2018 by the authors. Licensee MDPI, Basel, Switzerland. This article is an open access article distributed under the terms and conditions of the Creative Commons Attribution (CC BY) license (http:/ / creativecommons.org/licenses/by/4.0/). 